\title{
Job Satisfaction Factors Among English Language Teachers In Malaysia
}

\author{
Sara Zarisfizadeh \\ Faculty of Educational Studies \\ University Putra Malaysia \\ Tele: (+60) 0147343972 E-mail: sarazarisfizadeh@gmail.com
}

Received: 14-06- 2012

doi:10.7575/ijalel.v.1n.4p.30
Accepted: 07-07- 2012

Published: 01-09- 2012

URL: http://dx.doi.org/10.7575/ijalel.v.1n.4p.30

\begin{abstract}
Job satisfaction is very essential to the continuing growth of educational systems around the world and actually nowadays teachers have a very crucial role in the success or failure of each educational system. The present study investigated different job satisfaction and dissatisfaction factors among Malaysian English language teachers. The study is a survey research which has 35 English teachers as its participants. To collect data the questionnaire titled 'TEJOSAMOQ' was used. Descriptive analysis method was used to have sum of values, mean and standard deviation for each factor. The result showed that personal growth and achievement is the most important job satisfaction factors while high workload is central source of dissatisfaction for English teachers in Malaysia. The result can be used to make better and more effective policies and administration to have high quality education system in future.
\end{abstract}

Keywords: job satisfaction factors, job dissatisfaction factors, English language teachers

\section{Introduction}

During the recent decades many factors such as increasing global competitions make all the professionals around the world feel an increasing pressure in their work life. More ever the job of teaching in entire world especially in Third World countries is becoming more challenging than before, because today teachers have more roles and responsibility in schools. Nowadays teaching is accepted as a challenging job and one of the most important reasons is that in today's societies information is easily accessible so it can question the traditional role and job of teacher. According to Almiala's findings (2008)" many newly qualified teachers often resign from their teaching job within first few years because of low salary and burdening workload"(Almiala 2008:6-7) .As many studies have showed teachers' problems and all factors which related to them make the educational systems to face with many different kinds of problems, so such information about the elements which make job satisfaction or dissatisfaction in teachers is needed to improve the educational systems in Third World countries. There are many studies about job satisfaction of workers in general and also a lot on teachers' job satisfaction, but a few studies have been concentrated to find out different factors of job satisfaction and source of dissatisfaction for language teachers in different contexts. Just some studies like Marlow et al (1996) has investigated reasons for teachers leaving their professions.

Hence the present study considers the Evans' theory and tries to investigate job satisfaction factors among English teachers in Malaysia, the country where English is thought as a second language and it is hoped that the results make the readers to think more about providing ways to improve the job satisfaction, especially in language teachers who face with many challenges in every section in classes.

The following research questions were addressed to meet the objective of the study:

1. What are the most important job satisfaction factors for English language teachers in Malaysia?

2. What are the most important job dissatisfaction sources for English language teachers in Malaysia?

\subsection{Definitions}

Job satisfaction is a difficult concept to define. Researchers like Cranny, Smith and Stone (1992) have presented a general definition of job satisfaction. They have defined it as "an affective (emotional) reaction to a job that 
International Journal of Applied Linguistics \& English Literature

ISSN 2200-3592 (Print), ISSN 2200-3452 (Online)

Vol. 1 No. 4; September 2012

results from the incumbent's comparison of actual outcomes with those that are desired (expected, deserved, and so on.)"

Spector (1997) defines job satisfaction as "how people feel about their jobs and different aspects of their jobs". Some new researchers like Evans have different ideas, for example, Evans (1998) believes that job satisfaction has not been defined clearly enough in the past it lacks the deep definition of satisfaction which has made problems for research. He noted that researchers need to emphasize on the states of the person's mind more.

\subsection{Approaches}

Among different ways of approaching job satisfaction the global approach is the oldest one which has concentrated to find out the general job satisfaction of workers. According to Spector (1997) the global approach is useful when the researcher wants to find out the possible effects of satisfaction or dissatisfaction.

The other approach is facet approach which involves finding out which elements of the job all contribute to job satisfaction. The present study uses the facet approach to find out different elements which are the most important sources of job satisfaction and dissatisfaction for English language teachers.

There are different hypothesizes and theories in job satisfaction field. For example, Spillover hypothesis, Evans's job satisfaction theory and some content theories like Maslow's need hierarchy theory and Herzberg's motivation-hygiene theory.

Spector (1997) defined the Spillover hypothesis as the feelings we have in different areas of our lives tend to spill over and affect other areas. So many factors can affect on our well-being at work.

Evans' theory of job satisfaction (1997-1998) is only about teachers' job satisfaction. Her theory has its roots in Herzberg's theories and is one of the most recent theories on job satisfaction that concentrates on the job satisfaction of teachers.

Evans (1997) noted that" Herzberg's (1966) theory is difficult to use in studies of teacher job satisfaction because he does not provide a thorough definition of job satisfaction."

The Maslow's theory (1954) is a "positive theory of motivation that derives directly from clinical experience" and Herzberg's motivation-hygiene theory (1966) which also known as the two-factor theory is based on the concept that humans have two different needs: 1. Animalistic need 2. Human needs.

\subsection{Factors in job satisfaction}

According to Herzberg (1966) there are two factors:

\section{Hygiene factors}

The Motivation factors are factors which "bring the most job satisfaction to workers, and they include mostly intrinsic aspects of the job that related to human's psychological growth needs" and Hygiene factors are the animal needs such as work context or environment which merely prevent dissatisfaction but do not bring satisfaction. Herzberg (1959) has noted that "when workers do not have enough motivating factors in their jobs they must have even more hygiene factors because otherwise they will not be able to tolerate their job at all."

There are two important terms which affect the teachers' job satisfaction.

1. Realistic expectations. $\quad 2$. Relative perspective.

Evans (1998) explained the Realistic expectations as "the expectations a teacher has toward his or her job and when the expectations are realistic and met in their jobs, the teacher will be satisfied "and he defined the Relative perspective as" the views which teachers presently have towards their jobs that are shaped by their earlier experiences".

\section{Previous studies on teacher job satisfaction}

Majority of the researches which has been concentrated on teachers' job satisfaction are quantitative. Just a few researchers like Evans (1998) has studied job satisfaction of teachers by combining interviews with other methods and the others have used a combination of qualitative and quantitative methods like Chen (2010), Ducharme and Martin( 2000).

Evans conducted a pilot study in 1988 to study the level of morale and job satisfaction of the teachers and areas which had an effect on them. 
Her study's results showed that all of the teachers had varied views on the factors of job satisfaction. For example, many teachers were dissatisfied with how the school management was running the school and some of the teachers were ready to leave their jobs. Among the participant, some of them did not mind how the school was run. Evans concluded that the teachers are different, have individualistic views and experiences of morale and job satisfaction. Most importantly, her study revealed that the teachers' views are different in professionality, relative perspective and realistic expectations. Mäenpää (2005) study had similar results .she studied upper secondary school teachers' job satisfaction and the result showed that many of the teachers had very differing views towards their jobs.

She used interviewing and the results show that half of the teachers were satisfied with their job and the rest were dissatisfied. The most satisfaction factors to the teachers were working with other teachers as well as students. Sources of dissatisfaction were the teaching material, working conditions, the principal, workload and pay.

Klassen and Anderson (2009) studied the level of job satisfaction and sources of dissatisfaction of secondary school teachers in England. They started their study in 2007 and the main goal was to compare the results of the study to other ones which were carried out in the UK in 1962.

The result showed that teachers were less satisfied in general in their jobs as teachers in 1962. They compared their own result to Rudd and Wiseman's study. They found out that the most important dissatisfaction sources for teachers in 2007 is teaching itself (time demands and pupils' behavior) while Teachers in 1962 were most dissatisfied with external sources such as salary, condition of buildings and equipment and poor human relations. Furthermore, the Klassen and Anderson (2007) study's results showed that there were no differences between teachers' years of teaching experience and gender.

More recent studies have been done to investigate: 1. Motivation factors in teachers' job satisfaction and 2. Financial issues \& salary and their effects on teachers' job satisfaction. For example, Sabry.M (2010) studied the longitudinal effects of a pay-increase schema on teachers' job satisfaction. In the study 155 Egyptian primary school teachers responded to a questionnaire.

The study's first hypothesis was “There will be no effect of pay increase on teachers' job satisfaction" (sabry.M 2010:13) and the result showed that pay increase did not have a significant effect on teachers' job satisfaction, $F$ $(3,141)=1.24, n s,=0.005$. Thus, the analysis of the dataset supported the first hypothesis. The study's more hypothesizes have been conducted to investigate the effect of pay increase on teachers' job satisfaction by considering the differences in teachers' academic attainments, teachers' gender and teachers' length of service.

The result shows that there was a significant interaction effect between pay increase and teachers' academic attainments, $\mathrm{F}(3,141)=9.72, \mathrm{p}<0.01, \mathrm{p}^{2}=0.12\left(\mathrm{z}^{2}\right.$ refers to Eta Squared for effect size. $\left.\mathrm{p}<0.01\right)$. It means that the impact of the pay increase on teachers' job satisfaction differed significantly across teachers' academic attainments. For teachers 'gender item, the results $\left(\mathrm{F}(3,141)=12.43, \mathrm{p}<0.01, \mathrm{y}^{2}=0.14\right)$ show that the impact of pay increase on teachers' job satisfaction differed significantly across male and female teachers and support the hypothesis. Data analyzing shows that there was not a significant interaction effect between pay increase and teachers' length of service $\left(\mathrm{F}(6,284)=1.11\right.$, ns, $\left.\eta^{2}=0.001\right)$. This nonsignificant interaction effect indicates that the effect of pay increase on teachers' job satisfaction did not differ significantly across teachers' length of service, so the results did not support the fourth hypothesis of the study.

Ezgi (2011) studied the level of teachers' job satisfaction and motivation at EULEPS (the European University of Lefke, English Preparatory School).He conducted a survey research with a sample a total of 16 Egyptian English language teachers. The study revealed the factors which were dissatisfaction sources for teachers and also it highlighted the motivating factors for the teachers. The results showed that the three most positive motivational factors of the teachers were: 1 . appropriateness of course books (88\%) 2. help of colleagues (81\%) and 3. Promoting professional development (81\%). In the same time the study tried to find out the most important demotivational factors for teachers at EUL, EPS and the results revealed that 1 . Constant changes of EPS Administration (82\%) 2. Income (75\%) and 3. Annual salary increments (56\%) were the main demotivational factors.

\section{Method}

The study is a descriptive survey research to find out different factors which affect job satisfaction between language teachers in Malaysia. 


\subsection{Instrument}

To have desired information the questionnaire titled TEJOSAMOQ (Teachers' job Satisfaction and Motivation Questionnaire, Ololub 2006) was used .It has three different sections, part 1 includes 11 factors of job satisfaction which are divided in two categories, hygiene factors and motivator factors. There are 4 values in this part 1 to 4 , number 1 represents strongly disagree value and 4 represents strongly agree value. In part 2 participants are asked to arrange 12 factors from the most important source of job satisfaction number1 to the least important factor number 12.Part 3 includes 17 factors about sources of job dissatisfaction which have 4 values to choose. Values are from 1 to 4 which number 1 represents not dissatisfied value and nubmer4 represents strongly dissatisfied value.

\subsection{Participants}

The sample of the study is 35 English teachers who are chosen nun randomly and involve $11.4 \%$ males and $88.6 \%$ females. The back ground questionnaire is designed by the researcher and is confirmed by the study's supervisor, Dr. Vahid Nimehchisalem. The major nationalities are Malay 37.1\%, Indian 34.3\% and then Chinese nationality $5.7 \%$ and $22.9 \%$ of them come from other nationalities. $40 \%$ of the participants are single and $60 \%$ are married. For their education level, 57.1\% have bachelor degree, $40 \%$ have MB and 2.9\% has PHD degree. There are different levels of teaching among the participants, $37.1 \%$ of them teach in elementary school, $20 \%$ secondary school, $14.3 \%$ high school and $22.9 \%$ of them teach in college and $5.7 \%$ of them teach in universities. Among the participants $85.7 \%$ are full time teachers, $5.7 \%$ work as part time teachers and $8.6 \%$ are self-employed.

Table 3.2.1. Descriptive statistics results of the demographic questionnaire $(\mathrm{N}=35)$

\begin{tabular}{|c|c|c|c|}
\hline Demographic & categories & frequency & Percentage (\%) \\
\hline \multirow[t]{2}{*}{ gender } & male & 4 & $11.4 \%$ \\
\hline & female & 31 & $88.6 \%$ \\
\hline \multirow[t]{4}{*}{ nationality } & Malay & 13 & $37.1 \%$ \\
\hline & Chinese & 2 & $5.7 \%$ \\
\hline & Indian & 12 & $34.3 \%$ \\
\hline & other & 8 & $22.9 \%$ \\
\hline \multirow{2}{*}{$\begin{array}{l}\text { Married } \\
\text { status }\end{array}$} & single & 14 & $40 \%$ \\
\hline & married & 21 & $60 \%$ \\
\hline \multirow{3}{*}{$\begin{array}{l}\text { Education } \\
\text { level }\end{array}$} & Bachelor & 20 & $57.1 \%$ \\
\hline & Master of bachelor & 14 & $40 \%$ \\
\hline & PHD & 1 & $2.9 \%$ \\
\hline \multirow{5}{*}{$\begin{array}{l}\text { Level of } \\
\text { teaching }\end{array}$} & Elementary school & 13 & $37.1 \%$ \\
\hline & Secondary school & 7 & $20 \%$ \\
\hline & High school & 5 & $14.3 \%$ \\
\hline & College & 8 & $22.9 \%$ \\
\hline & University & 2 & $5.7 \%$ \\
\hline \multirow{3}{*}{$\begin{array}{l}\text { Employment } \\
\text { status }\end{array}$} & Full-time & 30 & $85.7 \%$ \\
\hline & Part-time & 2 & $5.7 \%$ \\
\hline & Self-employed & 3 & $8.6 \%$ \\
\hline
\end{tabular}

\subsection{Statistical Analysis Method}

The statistical analysis was carried out by using SPSS version 20 and descriptive statistic analysis was used to determine which factors are the sources of job satisfaction and job dissatisfaction among language teachers in Malaysia. 
International Journal of Applied Linguistics \& English Literature

ISSN 2200-3592 (Print), ISSN 2200-3452 (Online)

Vol. 1 No. 4; September 2012

\section{Results}

The collected date was analyzed by using descriptive statistic method and the results show that such motivator factors like sense of achievement with obtained value 124(maximum value 140) and mean 3.5 with SD 0.6, responsibility with the job with obtained value 122 , mean 3.4 and SD 0.6 and job security factor with obtained value 122, mean 3.4 and SD 0.6 are the most important and popular job satisfaction factors for language teachers.

Table 4.1. Descriptive statistic for hygiene and motivator job satisfaction factors

\begin{tabular}{llllc}
\hline Job satisfaction factors & $\mathrm{N}$ & Sum & Mean & Std. Deviation \\
\hline sense of achievement & 35 & 124.00 & 3.5429 & .65722 \\
responsibility within the job & 35 & 122.00 & 3.4857 & .65849 \\
job security & 35 & 122.00 & 3.4857 & .65849 \\
advancement and personal growth & 35 & 114.00 & 3.2571 & .74134 \\
salary and benefits & 35 & 107.00 & 3.0571 & .93755 \\
recognition my boss and others & 35 & 105.00 & 3.0000 & .84017 \\
working condition & 35 & 103.00 & 2.9429 & .68354 \\
the work itself & 35 & 98.00 & 2.8000 & .75926 \\
interpersonal relationship & 35 & 96.00 & 2.7429 & .85209 \\
ministry policies & 35 & 92.00 & 2.6286 & .54695 \\
levels and quality of supervision & 35 & 91.00 & 2.6000 & .73565 \\
\hline
\end{tabular}

In the second part of the questionnaire, the participants were asked to arrange 12 sources of job satisfaction and the results show that the most important factor is payment and fringe benefits with obtained value 170, mean 4.8 and SD 3.4 and then such factors like job security (obtained value 171, mean 4.8, SD 3.2) and opportunity for advancement (obtained value 172, mean 4.9, SD 2.8) are next important factors to have enough job satisfaction between Malaysian language teachers.

Table 4.2. Descriptive statistic for arranging the sources of job satisfaction

\begin{tabular}{lllll}
\hline Sources of job satisfaction & N & Sum & Mean & Std. Deviation \\
\hline recognition by others & 35 & 308.00 & 8.8000 & 2.41076 \\
making contribution to national development & 35 & 293.00 & 8.3714 & 3.42212 \\
status, important\& influential & 35 & 286.00 & 8.1714 & 3.38236 \\
responsibility within the job & 35 & 248.00 & 7.0857 & 3.58404 \\
being creative and taking new challenges & 35 & 244.00 & 6.9714 & 3.16679 \\
work itself & 35 & 222.00 & 6.3429 & 4.12270 \\
authority and independence & 35 & 220.00 & 6.2857 & 2.73938 \\
personal growth & 35 & 204.00 & 5.8286 & 3.12001 \\
achievement and standards & 35 & 186.00 & 5.3143 & 2.82605 \\
opportunity for advancement & 35 & 174.00 & 4.9714 & 2.89508 \\
job security and working condition & 35 & 171.00 & 4.8857 & 3.29680 \\
pay and fringe benefits & 35 & 170.00 & 4.8571 & 3.49910 \\
\hline
\end{tabular}


In the last part, the study tries to find out factors which make job dissatisfaction among teachers and the result show that the participants believe such factors like too much work and policy and administration with obtained value 100(maximum value 140) mean 2.8 and SD 0.9 are the most important job dissatisfaction factors and then urgent work ( obtained value 99, mean 2.8, SD 0.7) and little time for family and home ( obtained value 91, mean 2.6, SD 1.09) are next dissatisfaction sources among language teachers in Malaysia.

Table 4.3. Descriptive statistic for job dissatisfaction factors

\begin{tabular}{lrrrr}
\hline Dissatisfaction factors & N & \multicolumn{1}{c}{ Sum } & Mean & \multicolumn{1}{c}{ Std. Deviation } \\
\hline too much work & 35 & 100.00 & 2.8571 & .94380 \\
policy\& administration & 35 & 100.00 & 2.8571 & .60112 \\
urgent work & 35 & 99.00 & 2.8286 & .70651 \\
time for family \&home & 35 & 91.00 & 2.6000 & 1.09006 \\
hassles & 35 & 91.00 & 2.6000 & .77460 \\
pay/salary & 35 & 91.00 & 2.6000 & .91394 \\
negative feedback & 35 & 90.00 & 2.5714 & .60807 \\
fringe benefits & 35 & 90.00 & 2.5714 & .65465 \\
lazy\& incompetence & 35 & 87.00 & 2.4857 & .95090 \\
promotion opportunity & 35 & 87.00 & 2.4857 & .88688 \\
technical supervision & 35 & 86.00 & 2.4571 & .65722 \\
lack of status & 35 & 84.00 & 2.4000 & .77460 \\
failure to achieve & 35 & 83.00 & 2.3714 & .73106 \\
training opportunity & 35 & 82.00 & 2.3429 & .99832 \\
too little work & 35 & 81.00 & 2.3143 & .99325 \\
interpersonal relationship & 35 & 76.00 & 2.1714 & .74698 \\
job security \& stability & 35 & 73.00 & 2.0857 & .88688 \\
\hline
\end{tabular}

\section{Discussion and conclusion}

During the recent decades teachers' roles become more important and effective in education systems and it highlights the importance of job satisfaction in teachers which have direct effect on quality of teaching and learning progresses. It makes that in entire world all education systems try to have more satisfied teachers to have better results. In fact, teaching is that nothing is more central to student learning than the quality of teacher" (Galluzzo, 2005). Having information about factors which make teachers to have job satisfaction and categorizing them can help to save money and time to have more effective curriculum planning to get high quality in education systems in future.

The present study's results can reveal some important factors which can involve in two different packages of Malaysian English teachers' job satisfaction sources. The most important packages are personal growth and achievement which is first package and next one is financial issues and job security. To know the sources of job dissatisfaction is also useful and necessary information which can help to find out which issues make teachers to feel bad toward their career, and the study's results show that Malaysian teachers are so busy with too much working in their teaching which is the most important and popular dissatisfaction factor to lead them not to have enough time for family and home. It helps to understand why they chose policy and administration issues as one of dissatisfaction sources. By comparing the study's results with other studies, we can see many similarities which show how much the education ministries' decisions can affect on how teachers approach their job. For example Evans's study showed that majority of teachers are dissatisfied about how the schools are been managed (Evans 1988) or Maenpaa's study result (2005) revealed that teachers did not like their working conditions and like Malaysian teachers complain about workload and principles. All these studies can highlight the important role of education ministries to prepare basic and essential principles to make teachers satisfied in the entire world. Many studies like Evans (1988) have showed that salary is an important source of dissatisfaction for teachers. Her study found out that many teachers wanted to leave their job because of law salary while they should work hard and much. But the present study's results show that Malaysian English teachers feel satisfied about their salary. 
Some studies' results which have been done in Malaysia can support the findings. For example, Mukundam.J, Niemehchisalem.V and Hajimohammadi R (2011) have reported that majority of Malaysian teachers (more than $40 \%$ of the respondents) have chosen release time as their incentive to participant in professional development activities. They preferred to have more free time to live while just $8.3 \%$ of their participants have chosen to have a rise in their salary. So as this study and many other investigations have shown that the financial issued are not the main preoccupation for Malaysian English teachers.

The results can give good ideas about different job satisfaction and dissatisfaction factors for Malaysian English teachers but unfortunately the study could not have a huge number of participants so it was not possible to use factor analysis statistic method to analyze the data to categorize all factors properly which were asked. So for future studies, the researcher suggests to investigate different job satisfaction and dissatisfaction sources in huge number of language teachers to have the best categorized factors to use in future. Even more it is really valuable to study these factors and sources in different context, for example, societies where English is thought as a foreign language and in countries where it is thought as second language and compare the factors in these different situations. More social studies are suggested to find out which variables affect teachers to choose different factors. Surely having all these kind of information can give a broad perspective to plan education curriculum better and being more successful in each context in future.

\section{References}

Almiala, M. (2008). Mieli paloi muualle - opettajan työuran muutos ja ammatillisen identiteetin rakentuminen [online]. Faculty of Education / Education and Adult Education Dissertation. Publications in Education 128. Joensuu: University of Joensuu. (14 April 2011) http://epublications.uef.fi/pub/urn

Chen, J. (2010). Chinese middle school teacher job satisfaction and its relationships with teacher moving [online]. Asia Pacific Educ. http://www.springerlink.com/content/d5058j601h030g36/

Ducharme, L. \& Martin, J. (2000). The Unrewarding Work, coworker support, and job satisfaction [online]. Work and occupation, 27. http://wox.sagepub.com/content/27/2/223

Evans. L. (1997). Addressing problems of conceptualization and construct validity in researching teachers' job satisfaction. Educational Research.

Evans. L. (1998). Teacher Morale, Job Satisfaction and Motivation. London: Paul Chapman Publishing Ltd.

Ezgi .U. (2011). A study on motivation and job satisfaction of language teachers at the European university of Lefke, English preparatory school, 2nd International Conference on New Trends in Education and Their Implications. Antalya-Turkey

Galluzzo, G. (2005). Performance assessment and reviewing teacher education: the possibilities of NBPTS standards. Academic Research Library.

Herzberg, F. (1971). Work and the nature of man. New York: The World.

Herzberg, F. (1959). The motivation to work. New York: John Wiley \& Sons

Klassen, R.M. \& Anderson, C.J.K. (2009). How times change: secondary teachers' job satisfaction and dissatisfaction in 1962 and 2007 [online]. http://dx.doi.org/10.1080/01411920802688721

Locke, E.A. (1976). The nature and causes of job satisfaction, Handbook of industrial and organizational psychology. Chicago: Rand McNally College

Mäenpää, M. (2005). Teachers of English in Finnish upper secondary general school and their job satisfaction [online].https://jyx.jyu.fi/dspace/bitstream/handle/123456789/7391/URN_NBN_fi_jyu- 2005239

Maslow, A. (1970). Motivation and personality. New York: Harper Collins Publishers.

Mukundam.J, Niemehchisalem.V, \& Hajimohammadi R. (2011). How Malaysian School Teachers View Professional Development? Journal of International Education Research, 7.

Ololube, N. P. (2006). Teachers job satisfaction and motivation for school effectiveness: an assessment. Essays in Education, 18.

Sabry .M. (2010). Longitudinal Effects of Pay Increase on Teachers' Job Satisfaction: A Motivational Perspective. The Journal of International Social Research, 3 (10).

Spector, P.E. (1997). Job satisfaction: application, assessment, causes and consequences. Thousand Oaks, CA: Sage. 